\title{
Znaczenie pokoju i stabilizacji dla europejskiej polityki rozwojowej wobec Afryki Subsaharyjskiej
}

\begin{abstract}
Streszczenie: Celem globalnej polityki rozwojowej jest likwidacja ubóstwa. Badacze nie mają wątpliwości, że jedną z kluczowych barier w skutecznej walce z ubóstwem są wojny i konflikty zbrojne. Pokój i bezpieczeństwo są ważne zarówno dla państw rozwijających się, jak i dla państw świadczących pomoc rozwojową. UE i jej państwa członkowskie są największymi dawcami pomocy na świecie, a Afryka Subsaharyjska (SSA) regionem o największym zapotrzebowaniu na pomoc rozwojową. Tekst analizuje jakie miejsce w europejskiej polityce rozwojowej wobec Afryki zajmuje kwestia pokoju i stabilizacji? Drugim obszarem analizy jest próba odpowiedzi na dylemat w jaki sposób pokój i stabilizacja lub ich brak wpływają na rozwój Afryki Subsaharyjskiej? Z analizy sytuacji państw SSA wynika, że trwały, zrównoważony rozwój w warunkach wojny czy innych konfliktów zbrojnych nie jest możliwy. Budowanie trwałego rozwoju musi być poprzedzone skutecznym zakończeniem konfliktów oraz wyeliminowaniem lub radykalnym ograniczeniem ich przyczyn. Pomoc z zewnątrz, w tym pomoc UE, ma w tych krajach - przede wszystkim - charakter pomocy humanitarnej. Jest ona potrzebna i ratuje ludzkie życie. Sama w sobie nie likwiduje jednak przyczyn konfliktów, ani nie jest w stanie zapewnić trwałego rozwoju.
\end{abstract}

Słowa kluczowe: Afryka, rozwój, bezpieczeństwo, Unia Europejska, niestabilność

C elem globalnej polityki rozwojowej jest likwidacja ubóstwa. Cel ten został sformułowany w roku 2000 w postaci Milenijnych Celów Rozwojowych (MDGs). Został on potwierdzony we wrześniu 2015 przez United Nations Sustainable Development Summit, podczas którego przyjęło nową agendę rozwojową na kolejne 15 lat - do roku 2030. Obie globalne agendy rozwojowe były i są popierane przez wszystkie państwa członkowskie UE i Unię Europejską, jako organizację. Pierwszym z 17-tu nowych Celów Zrównoważonego Rozwoju (SDGs) jest: „Likwidacja wszystkich form ubóstwa”. Politycy i badacze nie mają wątpliwości, że jedną z kluczowych barier w skutecznej walce $\mathrm{z}$ ubóstwem są wojny i konflikty zbrojne. W preambule dokumentu końcowego Szczytu kwestię pokoju opisano krótko: „Jesteśmy zdecydowani wspierać pokojowe, sprawiedliwe i inkluzywne społeczności, które są wolne od strachu i przemocy. Nie może być zrównoważonego rozwój bez pokoju i nie ma pokoju bez zrównoważonego rozwoju" (Transforming, 2015, s. 1).

Pokój i bezpieczeństwo są ważne zarówno dla państw rozwijających się, jak i dla państw świadczących pomoc rozwojową. UE i jej państwa członkowskie są największymi dawcami pomocy na świecie, a Afryka Subsaharyjska (SSA) regionem o największym zapotrzebowaniu na pomoc rozwojową. Warto zatem rozważyć, jakie miejsce w europejskiej polityce rozwojowej wobec Afryki zajmuje kwestia pokoju i stabilizacji? Równie ciekawe jest zagadnienie w jaki sposób pokój i stabilizacja lub ich brak wpływają na rozwój Afryki Subsaharyjskiej? 
Ważnym czynnikiem wzmacniającym znaczenie kwestii bezpieczeństwa dla polityki UE był zamach z 11 września $2001 \mathrm{r}$. Zwiększenie roli zagadnień związanych z bezpieczeństwem było też widoczne w obszarze SSA. Podejście UE do swej roli w zakresie bezpieczeństwa ewoluowało w czasie i obejmowało różne polityki unijne. Złożony charakter zagrożeń dla bezpieczeństwa, jak i sposobów zapobiegania tym zagrożeniom powodował, że kwestie związane z bezpieczeństwem były przedmiotem wspólnej polityki zagranicznej i bezpieczeństwa, polityki rozwojowej i polityki handlowej. UE deklaruje całościowe podejście do konfliktów. W swym komunikacie w sprawie zapobiegania konfliktom z kwietnia $2001 \mathrm{r}^{1}{ }^{1}$ Komisja Europejska (KE) odwołuje się do koncepcji stabilności strukturalnej. A stabilność strukturalna charakteryzuje się „zrównoważonym rozwojem gospodarczym, demokracją i szanowaniem praw człowieka, realnymi strukturami politycznymi, odpowiednimi warunkami środowiskowymi i społecznymi oraz zdolnością do zarządzania zmianami bez uciekania się do przemocy". KE wskazała też na elementy przekrojowe związane z konfliktami. Katalog ten obejmuje sześć obszarów: narkotyki, broń lekka, zarządzanie i dostęp do zasobów naturalnych, degradacja środowiska naturalnego, rozprzestrzenianie się chorób zakaźnych, migracje i handel ludźmi. Znaczenie stabilności Afryki dla Europy wynika z geografii i polityki. Jedną z konsekwencji bliskości geograficznej obu kontynentów jest potencjalna i faktyczna migracja. Wymiar polityczny wynika z wielu deklaracji UE, określających Afrykę jako partnera strategicznego i priorytetowego.

\section{Strategia bezpieczeństwa}

Kluczowym dokumentem, określającym stanowisko UE w szeroko rozumianych kwestiach bezpieczeństwa, jest Europejska Strategia Bezpieczeństwa (ESS) ${ }^{2}$, przyjęta w 2003 r. Szefowie państw i rządów UE uznali, że Unia „powinna być gotowa do współodpowiedzialności za bezpieczeństwo światowe i budowę lepszego świata" (Europejska Strategia, 2009, s. 28). Katalog zagrożeń dla bezpieczeństwa z perspektywy europejskiej obejmował: terroryzm, rozprzestrzenianie broni masowego rażenia, konflikty regionalne, niewydolność państwa i zorganizowaną przestępczość. Z perspektywy afrykańskiej istotne było to, że ESS uznawała multilateralizm i nadrzędną rolę ONZ w utrzymaniu światowego pokoju i bezpieczeństwa.

Bardzo dużo uwagi kwestiom bezpieczeństwa poświęcono podczas drugiego szczytu Unia Europejska-Afryka w Lizbonie (8-9 grudzień 2007 r.). Podczas szczytu przyjęto trzy dokumenty ${ }^{3}$. „Deklaracja Lizbońska” jako pierwszy cel partnerstwa UE i Afryki wymieniała pokój i stabilność. Spośród czterech głównych celów określonych w JEAS, aż trzy obejmowały obszary związane z pokojem. W pierwszym stwierdzano, że celem partnerstwa jest m.in. ,wzmocnienie związków instytucjonalnych i podejmowanie wspólnych wyzwań, w szczególności w zakresie pokoju i bezpieczeństwa" (The Africa-European Union, 2008, s. 14). W drugim mówiono wprost o „wzmocnieniu i pro-

${ }^{1}$ COM (2001) 211.

2 Dok. 15895/03.

3 „Deklaracja Lizbońska”, ,Wspólna Strategia Afryka-Europa” (JAES) i „Pierwszy Plan Działania na lata 2008-2010", którego celem było wdrożenie w życie strategicznego partnerstwa Afryki i UE. 
mowaniu pokoju, bezpieczeństwa, demokratycznych rządów i praw człowieka, podstawowych wolności, równości płci, zrównoważonego wzrostu gospodarczego, włącznie z industrializacją, a także regionalnej i kontynentalnej integracji w Afryce [...]". Lista wartości, które zamierzano promować była długa, ale nieprzypadkowo, na jej początku umieszczono pokój i bezpieczeństwo. Trzecim celem było ,promowanie i utrzymywanie skutecznego multilateralizmu, z silnymi, reprezentatywnymi i legalnymi instytucjami [...]". Instytucje te miałyby rozwiązywać długą listę problemów. Zaliczono do nich m.in. ,rozprzestrzenianie broni masowej zagłady i nielegalny handel bronią lekką".

Najobszerniejszą część JEAS poświęcono opisowi czterech strategii kierunkowych. Obszarem pierwszej z nich jest „pokój i bezpieczeństwo”. Szefowie państw i rządów deklarowali jednoznacznie: „Afryka i Europa rozumieją znaczenie pokoju i bezpieczeństwa jako wstępnych warunków rozwoju politycznego, gospodarczego i społecznego. Opowiadają się za holistycznym podejściem do bezpieczeństwa, obejmującym zapobieganie konfliktom, długoterminowe budowanie pokoju, rozwiązywanie konfliktów i odbudowę po zakończeniu konfliktu. Działania te powinny być powiązane z zarządzaniem i zrównoważonym rozwojem, a także uwzględniać zajęcie się przyczynami konfliktów". Celem strategii było też stworzenie mechanizmu przywracania, utrzymywania i budowania pokoju. Nazywano go Afrykańska Architektura Pokoju i Bezpieczeństwa (APSA). Wszystkie cele strategiczne, opisane w strategiach kierunkowych miały być realizowane poprzez osiem partnerstw tematycznych, określonych w „Pierwszym Planie Działania” na lata 2008-2010. Pierwsze z partnerstw było poświęcone sprawie pokoju i bezpieczeństwa.

Niezależnie od wysiłków obu stron sytuacja w zakresie bezpieczeństwa w Afryce nie jest obecnie lepsza niż była w roku 2007. Pokój i kwestia bezpieczeństwa nieustannie i nadal są jednym z głównych motywów współpracy Afryki i Unii Europejskiej. Wiodącym tematem IV szczytu Afryka-UE, który odbył się w dniach 2-3 kwietnia 2014 r. w Brukseli było ,inwestowanie w ludzi, dobrobyt i pokój”. „Deklaracja brukselska”, przyjęta na szczycie, dużo uwagi poświęciła kwestiom pokoju. „Pokój i bezpieczeństwo jest kluczowym warunkiem wstępnym dla rozwoju i dobrobytu” (pkt 8). Deklaracja potwierdzała multilateralizm, jako fundament zarówno unijnego, jaki i afrykańskiego podejścia do kwestii bezpieczeństwa poprzez odwołanie do celów i zasad Karty Narodów Zjednoczonych (pkt 9). Sformułowano też bardziej konkretne zapisy w tym zakresie: „Potwierdzamy naszą determinację, aby zapewnić, że instytucje wielostronne i zobowiązania traktatowe są główną platformą współpracy międzynarodowej w zakresie pokoju i bezpieczeństwa. Elementem niezbędnym dla osiagnięcia sukcesu jest ścisła współpraca między nami, a także współpraca $\mathrm{z}$ odpowiednimi organizacjami regionalnymi i subregionalnymi, ONZ i jej agencjami oraz innymi międzynarodowymi mechanizmami koordynacji" (pkt 20). Obie strony zobowiązywały się też do wzmocnienia wysiłków zmierzających do zwalczania: międzynarodowego terroryzmu, zorganizowanej przestępczości, handlu ludźmi, nielegalnego handlu zasobami naturalnymi i przemytu narkotyków (pkt 13). Jednocześnie wskazano nietradycyjne, nowe źródła zagrożeń dla pokoju i bezpieczeństwa: zmiany klimatyczne, zasoby wodne, bezpieczeństwo energetyczne i cybernetyczne (pkt 21).

Dramatyczny wzrost liczby uchodźców i imigrantów, przybywających do Europy w roku 2015 spowodował przedterminowe zwołanie kolejnego szczytu Afryka-UE, 
poświęconego wyłącznie migracji. Odbył się on w dniach 11-12 listopada 2015 r. na Malcie. Otwierając szczyt Donald Tusk, przewodniczący Rady Europejskiej powiedział m.in.: ,jednym z naszych najważniejszych zadań jest przeciwdziałać przyczynom obecnych ruchów migracyjnych. To my, przywódcy, musimy zadbać o to, by ludzie nie musieli ryzykować życia w celu zrealizowania swoich aspiracji. Bezpieczeństwo i szanse - nad tym Europa i Afryka już wspólnie pracują. I będą pracować nadal"4.

W szczycie uczestniczyli przedstawiciele ponad 60-ciu państw oraz instytucji UE i UA. W „Deklaracji politycznej” stwierdzali oni m.in. „Będziemy zwracać szczególną uwagę na stabilność i bezpieczeństwo, które jest obecnie zagrożone przez terroryzm, handel bronią i konflikty zbrojne. Zobowiązujemy się do sprostania tym wyzwaniom w skoordynowany sposób, w szczególności poprzez system wczesnego ostrzegania, zapobieganie konfliktom i rozwiązywanie konfliktów". Szczyt podjął też bardziej szczegółowe zobowiązania łączące kwestie bezpieczeństwa i rozwoju: „Zobowiązujemy się do zajęcia się przyczynami nielegalnej migracji i wymuszonego przemieszczenia się, wynikającymi z niestabilności państwa i brak bezpieczeństwa, jak również trendów demograficznych, ekonomicznych i środowiskowych. Nasza wspólna odpowiedź będzie koncentrować się na zmniejszeniu ubóstwa, wspieraniu pokoju, dobrych rządów, praworządności i poszanowania praw człowieka, wspieraniu wzrostu gospodarczego sprzyjającego włączeniu społecznemu dzięki możliwości inwestowania i tworzenia dobrych miejsc pracy, poprawy w zakresie świadczenia podstawowych usług takich jak edukacja, zdrowie i bezpieczeństwo".

Instrumentem, który ma pomóc w realizacji zobowiązań szczytu jest nowy fundusz - nadzwyczajny fundusz powierniczy na rzecz stabilności i zwalczania przyczyn nielegalnej migracji i wysiedleń w Afryce. Komisja Europejska przeznaczyła na ten instrument 1,8 mld euro z budżetu UE i z Europejskiego Funduszu Rozwoju (EFD). Fundusze „pozabudżetowe" pochodzą z rezerwy 11-ego EFD, a także ze środków z programów dla poszczególnych regionów SSA, a także środków z krajowych programów dla państw Rogu Afryki. Część „,budżetowa” pochodzi z Instrumentu Finansowania Współpracy na rzecz Rozwoju (DCI) i Europejskiego Instrumentu Sąsiedztwa (ENI). Z perspektywy współpracy rozwojowej nie są to zatem „dodatkowe” pieniądze. Nowy Fundusz ma być uzupełniany o wkłady państw członkowskich UE i innych darczyńców. Jednak do 12 listopada 2015 r. 25 państw członkowskich UE (z wyjątkiem Grecji, Cypru i Chorwacji) oraz Szwajcaria i Norwegia zdeklarowały stosunkowo niewielką kwotę $-81 \mathrm{mln}$ euro.

\section{Wspólzależność pokoju i rozwoju}

Ścisłą współzależność pokoju i rozwoju wykazywano wielokrotnie (Promoting democracy, 2005, s. 41). „Bez bezpieczeństwa rozwój jest bezowocny, bez rozwoju pokój jest bez sensu" (Development and Security, 2009, s. 8). Współzależność tą podkreślają też dokumenty unijne - Europejska Strategia Bezpieczeństwa (2003) i Europejski Konsensus w sprawie rozwoju (2006). Dlatego wiele organizacji uznaje, że zapobieganie i rozwiązywanie konfliktów i zwiększenie stabilności powinny być warunkami wstęp-

${ }^{4}$ „Wystapienie przewodniczącego Donalda Tuska rozpoczynające szczyt w Valletcie w sprawie migracji”, 808/15. 
nymi polityki rozwoju (EPP-ED Development, 2008, s. 39). Niemniej samo zagwarantowanie pokoju, nie jest warunkiem wystarczającym dla rozwoju. Amartya Sen ${ }^{5}$ uważał, że „rozwój wymaga usunięcia głównych źródeł zniewolenia: ubóstwa i tyranii, słabych możliwości ekonomicznych, a także systemowej deprywacji społecznej, zaniedbania infrastruktury publicznej, jak również nietolerancji i nadaktywności państw represyjnych" (Sen, 2000, s. 3). Z drugiej strony część badaczy uważa, że niesprawiedliwe reguły handlu światowego czy zmiany klimatyczne wywoływane, przede wszystkim, przez przemysł państw rozwiniętych są przyczynami zarówno nowych wojen, jak i najgorszych przejawów ubóstwa, do których zalicza się głód.

Globalna agenda rozwojowa obejmuje wszystkie państwa świata, ale poziom obecnego rozwoju poszczególnych regionów i państw jest bardzo zróżnicowany. Dlatego Cele Zrównoważonego Rozwoju mają największe znaczenie dla tych państw i regionów, które są najsłabiej rozwinięte. Hiruy Amanuel, ambasador Etiopii w Berlinie ${ }^{6}$ stwierdził, że Afryka jest dobrym przykładem tego, że „konflikt i ubóstwo żywią się wzajemnie” (11th EADI, 2006, s. 5). W przypadku SSA współzależność pokoju i rozwoju ma dwojakie znaczenie.

Po pierwsze: Afryka Subsaharyjska jest - bez wątpliwości - najbiedniejszym regionem świata. Dowodem są różne wskaźniki. W roku 2014, według danych Międzynarodowego Funduszu Walutowego, badającego produkt krajowy brutto (według parytet siły nabywczej) na mieszkańca, wśród 20 najbiedniejszych państw aż 18 było z SSA. $\mathrm{Z}$ perspektywy rozwojowej najważniejszą grupą docelową polityki rozwojowej w wymiarze globalnym są państwa zaliczane do grupy państw najsłabiej rozwiniętych - Least Developed Countries (LDCs). Po raz pierwszy lista krajów najsłabiej rozwiniętych, została określona przez ONZ w 1971 r. $^{7}$ Lista krajów najsłabiej rozwiniętych jest weryfikowana co trzy lata przez Radę Gospodarczą i Społeczną ONZ (ECOSOC). Obecnie najliczniejszą grupę państw w tej kategorii, stanowią państwa SSA. W 2014 r. spośród 48 państw kwalifikowanych jako LDCs, aż 34 to państwa $\mathrm{z}$ tego regionu (The Least, 2014, s. XIII).

Po drugie: liczba konfliktów zbrojnych w SSA jest wyższa niż w innych regionach świata. Wprawdzie areną najbardziej krwawych konfliktów (w kontekście liczby ofiar) jest środkowa i wschodnia Azja, ale spośród 17 konfliktów, które w 2014 r. pochłonęły więcej niż 1000 ofiar śmiertelnych, aż dziewięć miało miejsce w Afryce, a spośród nich siedem w SSA - Nigeria, Sudan Południowy, Somalia, Sudan, Republika Środkowoafrykańska (RCA), Kamerun, Demokratyczna Republika Kongo (DRC) (ACLED Realtime Data 2015). Dodatkowo wśród państw, w których w wyniku konfliktów zbrojnych zginęło w roku 2014 mniej niż 1000 osób są jeszcze trzy państwa regionu: Kenia, Mali i Etiopia. W 2015 r. w SSA miały miejsce konflikty zbrojne w państwach, które rok wcześniej nie były na liście najbardziej krwawych konfliktów. Od stycznia do października 2015 r. liczba ofiar śmiertelnych w Burundi to 169 osób, a w Nigrze - 500 .

Tak wysoka liczba konfliktów ma z kolei wpływ na poziom rozwoju poszczególnych państw i jakość życia ich mieszkańców, a co za tym idzie inne wskaźniki i rankingi. Na przykład większość państw definiowanych jako fragile states jest zlokali-

\footnotetext{
${ }^{5}$ Laureat Nagrody Banku Szwecji im. Alfreda Nobla w dziedzinie ekonomii w $1998 \mathrm{r}$.

${ }^{6}$ W latach 2002-2006.

${ }^{7}$ W rezolucji nr 2768 (XXVI) z dnia 18 listopada $1971 \mathrm{r}$.
} 
zowana w SSA. Najbardziej znanym miernikiem, dotyczącym stabilności jest Fragile States Index ${ }^{8}$, opracowany i obliczany przez Fund for Peace9. Wskaźnik ten dzieli państwa, w zależności od poziomu stabilności, na cztery kategorie: sustainable, stable, warning, alert. Wśród państw zaliczanych w 2015 r. do najwyższej kategorii very high alert są wyłącznie państwa SSA: Sudan Południowy, Somalia, RCA i Sudan. W kategorii high alert jest sześć państw: DRC, Czad, Gwinea, Nigeria, Zimbabwe i Wybrzeże Kości Słoniowej. W kategorii alert 14 państw SSA: Ruanda, Kongo, Sierra Leone, Mali, Kamerun, Mauretania, Erytrea, Uganda, Liberia, Kenia, Etiopia, Niger, Burundi and Gwinea-Bissau. Wśród 20 państw z najwyższym Fragile States Index aż 14 jest $\mathrm{z}$ tego regionu.

Unia Europejska odgrywa ważną rolę w próbach wspierania państw niestabilnych. UE wspiera „Zasady podejmowania działań międzynarodowych w niestabilnych państwach i sytuacjach niestabilności", przyjęte w 2007 r. przez OECD. Niemniej UE nie zrezygnowała $\mathrm{z}$ własnej polityki $\mathrm{w}$ tym zakresie. Od roku 2000 instytucje unijne przyjęły kilkanaście dokumentów uwzględniających problem niestabilności i reakcji na nią. Część z nich miała charakter bardziej ogólny, ale niektóre koncentrowały się bezpośrednio na niestabilności. W $2001 \mathrm{r}$. Rada przyjęła program zapobiegania konfliktom zbrojnym ${ }^{10}$, a Komisja Europejska opublikowała komunikat o zapobieganiu konfliktom ${ }^{11}$. W październiku 2007 r. KE przyjęła komunikat pt. „Strategie reagowania UE na sytuacje niestabilności - podejmowanie działań w trudnych warunkach na rzecz zrównoważonego rozwoju, stabilności i pokoju" ${ }^{2}$. Miesiąc później Parlament Europejski przyjął rezolucję „w sprawie reakcji UE na niestabilną sytuację w krajach rozwijających się"13. Stanowisko Parlamentu było bardzo ambitne. Proponowany harmonogram przeciwdziałania niestabilności powinien, zdaniem PE, uwzględniać trzy zagadnienia: bezpieczeństwo ludności, przyspieszenie rozwoju oraz gwarancję pokoju (pkt 5). Z kolei Rada kilkakrotnie przyjmowała konkluzje, dotyczące niestabilności: konkluzje Rady w sprawie ram politycznych reformy sektora bezpieczeństwa (2006), konkluzje Rady w sprawie reakcji UE na sytuacje niestabilności (2007), konkluzje Rady w sprawie bezpieczeństwa i rozwoju (2007), konkluzje Rady w sprawie zapobiegania konfliktom (2011), konkluzje Rady w sprawie Wspólnej Polityki Bezpieczeństwa i Obrony (2012). Instytucjom unijnym nie udało się jednak przygotować planu działania w sprawie niestabilności i konfliktów (EU Development, 2013, s. 15). Odpowiedzialność za realizację polityki UE wobec niestabilności jest rozproszona i podzielona między trzy struktury organizacyjne - ESDZ, DG DEVCO i służbę KE - Foreign Policy Instruments Service (FPI).

UE jest aktywnym uczestnikiem międzynarodowej sieci ds. konfliktów i niestabilności OECD oraz powołanego do życia w 2008 r. międzyrządowego Międzynarodowego

${ }^{8}$ The Fragile States Index jest rankingiem 178 krajów opracowanym na podstawie ich poziomu stabilności i problemów, które napotykaja.

${ }^{9}$ Organizacja określa samą siebie jako: „niezależna, bezpartyjna, [...] organizacja badawcza i edukacyjna nie działająca dla zysku, która pracuje na rzecz zapobiegania konfliktom z użyciem przemocy i promowania trwałego bezpieczeństwa" (Fragile States, 2015, s. 2).

${ }^{10}$ EU Programme of the Prevention of Violent Conflicts.

${ }_{11}$ COM (2001) 211.

${ }_{12}$ COM (2007) 643.

13 B6-0476/2007. 
Dialogu na rzecz Umocnienia Pokoju i Tworzenia Państw. UE i większość państw członkowskich uczestniczy również w kluczowej inicjatywie Dialogu, zapoczątkowanej na IV Forum Wysokiego Szczebla na temat Skuteczności Pomocy w Busan w listopadzie 2011 r., a zatytułowanej „Nowy ład na rzecz państw niestabilnych”. UE zaangażowała się w inicjatywę, gdyż jej cele miały pomóc w osiągnięciu MDGs, popieranych przez Unię. A z badań wynikało, że państwa narażone na konflikty zbrojne miały mniejsze szanse na zrealizowanie celów rozwojowych (Debiel, Werthes, 2006, s. 37).

Istotny wpływ konfliktów zbrojnych na rozwój wynika między innymi z bardzo wysokich kosztów prowadzenia konfliktów i utrzymania armii. Wydatki ponoszone globalnie na cele militarne są wielokrotnie większe niż globalne wydatki na pomoc rozwojową. Według Stockholm International Peace Research Instiute (SPIRI) w 2014 r. na obronność wydano na świecie 1767 mld USD (SIPRI Military Expenditure Database). W tym samym okresie globalna pomoc rozwojowa wynosiła, wg danych OECD, 135,1 mld USD. Państwa afrykańskie pod względem nominalnym nie są liderami wydatków militarnych, ale ich wydatki zbrojeniowe rosną. W latach 1999-2008 wzrosły o 40\% (Wulf, 2010, s. 19). SIPRI szacuje się, że od roku 2008 do 2014 wydatki państw SSA na cele militarne zwiększyły się z 20,9 do 30,1 mld USD. W wymiarze globalnym to niewiele, ale w porównaniu do PKB państw SSA, to znaczący wydatek. W niektórych przypadkach poziom wydatków militarnych jest bardzo wysoki w stosunku do PKB.

Państwem, które ma największy na świecie budżet wojskowy w porównaniu do swego PKB jest jedno z najbiedniejszych państw świata - Erytrea. Stanowi ona też ciekawy przykład wpływu konfliktu zbrojnego i utrzymującego się napięcia w relacjach z sąsiadami na rozwój państwa. Według SIPRI począwszy od roku 2003, gdy poziom wydatków militarnych wynosił 20,9\% PKB, nie ma wiarygodnych danych w tym zakresie. Rekordowy był rok $1999-34,4 \%$ PKB. Ma to olbrzymi wpływ na strukturę wydatków budżetu państwa. Erytrea w roku 2003 wydała 31,1\% swego budżetu na armię, a w rekordowym, pod tym względem, roku 1998 - aż 47,7\%. Aktualnie wydatki „obronne” stanowią prawdopodobnie ok. $25 \%$ budżetu jednego z najbiedniejszych państw świata. Prezydent Erytrei Isaias Afewerki nieustannie obawia się wojny z Etiopią. Cała polityka państwa jest temu podporządkowana, choć trzeba dodać, że jest to polityka jednoosobowa. Prezydent mówi bowiem: „Ja jestem rządem” (I am the government) ${ }^{14}$. Polityka prezydenta ma przemożny wpływ na funkcjonowanie zarówno państwa i społeczeństwa, jak i stopień rozwoju.

Uciążliwości związane z służbą wojskową i fakt, że długość obowiązkowej służby wojskowej jest praktycznie nieograniczona są jednymi z podstawowych przyczyn migracji Erytrejczyków do innych państw. Obowiązkową służbę wojskową wprowadzono dla kobiet i mężczyzn w 1995 r. Profesor Gaim Kibreab z London South Bank University, przeprowadził wywiady z 215 byłymi poborowymi. Służyli oni średnio po sześć i pół roku (Kibreab, 2014). Erytrejczycy to istotna grupa uchodźców afrykańskich, próbujących się dostać do UE. Z badań Prof. G. Kibreab’a wynika, że „tysiące Erytrejczyków każdego roku opuszcza swój kraj przede wszystkim, aby uniknąć poboru, który kojarzy im się z niewolnictwem".

\footnotetext{
${ }^{14}$ Podczas spotkania z delegacją Parlamentu Europejskiego w Massawa, 28 października 2008 r.
} 


\section{Wplyw konfliktów na rozwój}

Konflikty zbrojne mają istotny wpływ na rozwój. Wpływ ten na złożony charakter, a jego znaczenie dla rozwoju zależy od trzech podstawowych parametrów: długości, intensywności i zasięgu terytorialnego konfliktu. Różnice w zakresach tych parametrów są olbrzymie. Wojna domowa w Angoli trwała 27 lat (1975-2002). Konflikt graniczny Erytrea-Dżibuti w czerwcu 2008 r. trwał zaledwie kilka dni. W tym krótkim konflikcie życie straciło 35 żołnierzy Dżibuti (Report, 2008, s. 2). Wiele konfliktów w Afryce ma charakter lokalny i ogranicza się do jednej prowincji lub nawet jednej miejscowości. $\mathrm{Z}$ drugiej strony najkrwawszymi konfliktami w Afryce były wojny w DRC. O skali tego konfliktu świadczy również fakt, że Drugą Wojnę Kongijską (1998-2003) nazywa się czasami Afrykańską Wojną Światową i to, że były w nią zaangażowane siły zbrojne ośmiu państw. Po stronie rządu DRC - Angola, Czad, Namibia i Zimbabwe. Proruandyjskie milicje były wspierane militarnie przez Ruandę, Burundi i Ugandę. Druga Wojna Kongijska była najkrwawszą wojną od czasu zakończenia II wojny światowej. W jej wyniku życie straciło 5,4 mln ludzi, głównie w skutek głodu i chorób.

Oprócz ofiar śmiertelnych do skutków, które przynoszą konflikty zbrojne, można zaliczyć:

- osoby, które odniosły rany,

- przemieszczanie ludności (DPs, IDPs),

- problemy psychologiczne (gwałty, dzieci-żołnierze, rozprzestrzenianie chorób),

- problem obszarów zaminowanych,

- osłabienie lub wstrzymanie produkcji rolnej i przemysłowej,

- osłabienie lub wstrzymanie wymiany handlowej,

- straty w infrastrukturze technicznej,

- straty w infrastrukturze instytucjonalnej i społecznej,

- niekorzystne zjawiska społeczne np. piractwo,

- szkody dla środowiska naturalnego,

- wzrost wydatków na cele militarne,

- zagrożenie bezpieczeństwa żywnościowego,

- straty wizerunkowe - zmniejszenie bezpośrednich inwestycji zagranicznych.

Wpływ konfliktów na rozwój jest potwierdzony przez fakt, że państwa, które nie doświadczyły konfliktów zbrojnych, osiagają lepsze wskaźniki rozwoju społecznego (Ibidem, 42). Według ONZ wśród 20 państw o najniższym Human Development Index (HDI) 18 to państwa SSA. W XXI wieku tylko nieliczne z tych państw afrykańskich nie doświadczyły konfliktów zbrojnych (Malawi i Gambia).

Zdaniem wielu badaczy przyczyną słabego rozwoju SSA jest niezdolność liderów poszczególnych państw afrykańskich do wprowadzenia i utrzymania efektywnych rządów. (Meredith, 2011, s. 610). Jednak warunkiem wstępnym efektywnych rządów jest bezpieczeństwo. James Putzel ${ }^{15}$ twierdził, iż „pierwszym krokiem w budowie państwa jest zapewnienie bezpieczeństwa, bez którego żadna ilość pomocy rozwojowej i dobrego zarządzania nie może skutecznie zapobiec załamaniu" (Development and Security, 2009, s. 30). Afrykańscy liderzy hierarchię zadań rozwojowych postrzegają podobnie.

152009 - dyrektor Crises States Centre at the Development Studies Institute, London School of Economics and Political Science. 
Prezydent Senegalu Macky Sall w wywiadzie dla „Foregin Affairs” mówił: „Musimy zapewnić bezpieczeństwo naszych mieszkańców, nienaruszalności naszych granic, jak i stabilność naszych państw tak, abyśmy mogli skupić się na takich kwestiach, jak rozwój i ubóstwo" (Africa’s Turn, 2013, s. 5). Budowanie instytucji i potencjału państwa powinno zatem być głównym celem międzynarodowego zaangażowania w krajach niestabilnych.

Dobrym przykładem działania tego mechanizmu jest Sudan Południowy. Najmłodsze państwo świata w chwili uzyskiwania niepodległości (lipiec 2011 r.) stał się jednym z tzw. ulubieńców donatorów (aid darlings). W latach 2011-2012 Sudan Południowy otrzymał 2,7 mld USD oficjalnej pomocy rozwojowej (ODA). Dodatkowo w roku 2012 otrzymał $865 \mathrm{mln}$ USD w ramach międzynarodowej pomocy humanitarnej, co uczyniło go drugim największym odbiorcą pomocy humanitarnej na świecie. Sudan Południowy mógł skoncentrować się na rozwoju. Niestety bardzo szybko - już miesiąc po ogłoszeniu niepodległości - w sierpniu 2011 r. - wybuchły poważne walki plemienne. Od grudnia 2013 r. przybrały one formę wojny domowej. Szacuje się, że w jej rezultacie zginęło kilkadziesiąt tysięcy osób. W sierpniu 2015 r. strony podpisały kolejny rozejm, ale czy będzie on skuteczny, nie wiadomo. Poziom ODA utrzymuje się na wysokim poziomie i w 2014 r. wyniósł prawie 2 mld USD. W przeliczeniu na jednego mieszkańca Sudan Południowy jest największym odbiorcą ODA w Afryce. Według OECD są 162 USD na osobę (www.independent.co.ug, 4.02.2016).

Walki mają tragiczny i dewastujący wpływ na młode państwo. Liczbę osób przesiedlonych (IDPs) w grudniu 2014 r. szacowano na 1,4 mln (Internal Displacement Monitoring Centre). Przed wybuchem wojny domowej, perspektywy rozwoju Sudanu Południowego były optymistyczne. Dzisiaj ,perspektywy wzrostu gospodarczego pozostają niepewne, w dużej mierze zależne od ewolucji perspektyw przywrócenia pokoju i międzynarodowych cen ropy" (African Economic Outlook 2015). Dzisiaj, jak było wspomniane, Sudan Południowy jest liderem Fragile States Index. Według organizacji $\mathrm{ONE}^{16}$ jednym ze skutków wojny domowej, w połączeniu ze złymi zbiorami w roku 2015, było to, że kraj „opuścił co trzeciego spośród 4,6 mln ludzi, którzy tam mieszkają i są poważnie zagrożeni brakiem żywności lub nie mogą produkować lub zakupić odpowiedniego wyżywienia" (www.one.org, 5.02.2016). Ambitne plany rozwojowe zostały zablokowane przez wewnętrzny konflikt, paraliżujący państwo, borykające się z wieloma innymi problemami.

Ważnym dylematem polityki rozwojowej jest reakcja na wątpliwość czy, niezależnie od intencji donatorów, pomoc rozwojowa może w niektórych przypadkach napędzać konflikty (fuel conflicts). Największym konfliktem XXI wieku były wojny w DRC. Jason K. Stearns, dyrektor Usalama Project ${ }^{17}$ odniósł się do jednej ze spiskowych teorii w sprawie licznych walk w DRC. Teoria ta opiera się na założeniu, że donatorzy byli rzekomo zainteresowani „bałkanizacją” DRC, by łatwiej i taniej eksploatować surowce mineralne tego kraju. Jednym z argumentów zwolenników tej teorii jest pytanie o to, z jakiego innego powodu donatorzy finansowali prawie połowę budżetów DRC i Ruandy przez ostatnią dekadę? Odpowiedź Stearns'a na to pytanie jest inna: „Winą darczyńców nie są hegemoniczne ambicje, ale apatia i ignorancja. Kongo nie znajduje w czołowej

\footnotetext{
${ }^{16}$ Międzynarodowa organizacja rozwojowa, której współzałożycielem był Bono.

${ }_{17}$ Program badawczy dotyczący grup zbrojnych w Kongo prowadzony przez Rift Valley Institute.
} 
grupie priorytetów polityki zagranicznej Londynu, Paryża, Waszyngtonu czy Pekinu" (Stearns, 2013, s. 102). Wielu polityków, urzędników czy przedstawicieli międzynarodowych instytucji deklaruje wprawdzie, że Afryka w kontekście bezpieczeństwa jest priorytetem. Jednak często są to przykłady myślenia życzeniowego. Niewiele wskazuje, by bezpieczeństwo było dzisiaj rzeczywistym priorytetem najważniejszych donatorów.

Z drugiej strony obawy związane z potencjalnym przedłużaniem konfliktów poprzez pomoc rozwojową, w połączeniu ze wzmacniającym się nastawieniem na skuteczność pomocy (by pomoc rozwojowa przynosiła planowane i mierzalne rezultaty), skutkują tym, że fragile states stają się jednocześnie tzw. „sierotami pomocowymi” (aid orphans). Mechanizm tej zależności polega na tym, że donatorzy wycofują się z krajów, gdzie szansa na uzyskanie oczekiwanych, mierzalnych rezultatów jest mniejsza niż w krajach stabilnych, a na dodatek mogliby zostać obciążeni współodpowiedzialnością za przedłużanie konfliktów (Raport Europejski, 2009, s. 12). Istnieją wprawdzie narzędzia służące do badania czy dany poziom pomocy jest efektywny z punktu widzenia wzrostu (Raport Europejski, 2009, s. 13), ale w praktyce wiedza ta nie jest wykorzystywana przez donatorów. W konsekwencji z punktu widzenia efektywności część fragile states otrzymuje zbyt mało pomocy, a niektóre z nich za dużo.

\section{Rozwiązywanie konfliktów}

Kolejnym wyzwaniem politycznym jest fakt, że państwa afrykańskie nie są w stanie samodzielnie rozwiązywać konfliktów i przywracać bezpieczeństwa. We wspomnianym wcześniej wywiadzie, M. Sall mówił też: „Afryka nie może sama rozwiązać swych problemów, bo nie jesteśmy jeszcze w sytuacji, w której mielibyśmy logistyczne możliwości wysłania wojsk w nagłych przypadkach. To po prostu kwestia środków, a nie ludzi" (Africa's Turn, 2013, s. 5). Nie zawsze jest to tak proste, jak przedstawia prezydent. Czasami państwa SSA nie mają woli politycznej by interweniować. A bywa i tak, że głównym motywem interwencji wojskowej w innym państwie nie jest troska o jego stabilność, tylko doraźne bądź strategiczne interesy polityczne państwa interweniującego. Czasami z kolei nie ma nawet woli by zaangażować się politycznie. Jednym z wielu przykładów może być to, że podczas 15 -ego Wspólnego Zgromadzenia Parlamentarnego AKP-UE w Ljubljanie w marcu 2008 r. nie udało się przyjąć projektu rezolucji w sprawie sytuacji w Czadzie. Projekt został odrzucony z powodu braku wystarczającego poparcia delegatów AKP.

Niezależnie od umiejscowienia bezpieczeństwa na różnych listach priorytetów, społeczność międzynarodowa, w tym UE, próbuje pomóc państwom afrykańskim w rozwiązywaniu konfliktów zbrojnych. Dla państw afrykańskich najbardziej akceptowalną politycznie formą są misje pokojowe, realizowane na podstawie mandatu ONZ. Donatorzy wiedzą, że trwałe rozwiązanie konfliktów wymaga zlikwidowania przyczyn tych konfliktów. Jednocześnie nie wszyscy donatorzy chca, a czasami nie mają możliwości, by angażować się $\mathrm{w}$ interwencje o charakterze militarnym, których celem jest przywrócenie pokoju. Inni donatorzy z kolei interweniują często, ale z reguły czynią to w państwach, z którymi utrzymują szczególne stosunki. Najczęściej są to byłe kolonie lub państwa, z którymi utrzymują silne więzi gospodarcze, kulturalne i polityczne. Poszczególne państwa członkowskie 
UE interweniowały militarnie w Afryce dziesiątki razy. Tylko Francja w postkolonialnej Afryce dokonała ponad 30 interwencji wojskowych (Huliaras, 2009, s. 35). Niezależnie od interwencji, Francja utrzymuje stałą obecność wojskową w Afryce. Bazy wojskowe Francji mają znaczenie polityczne i ekonomiczne, a armia francuska angażuje się w działania humanitarne i rozwojowe (Solarz, 2004, s. 233).

O ile samo wykorzystanie wojska do akcji humanitarnych nie budzi większych zastrzeżeń, tak motywy stojące za takim zaangażowaniem czy udział armii w projektach rozwojowych spotyka się z krytyczną analizą organizacji pozarządowych. Janina Ochojska pisała: „Jeżeli w motywacji oraz strategii pomocy przeważa własny interes i korzyści, to dobro ludzi, którzy potrzebują pomocy, jest zagrożone. Jeżeli motywacją jest „zdobycie serc i umysłów” to mamy do czynienia z manipulacją, służącą ochronie własnych interesów. Taka była motywacja USA podczas wojny wietnamskiej” (Kto niesie pomoc?, 2011, s. 3). Organizacje OXFAM i Polska Akcja Humanitarna (PAH) uważaja, że nie powinno się ,pozwalać na takie alokowanie lub ograniczanie pomocy humanitarnej, które będzie wynikać z celów wojskowych lub antyterrorystycznych" (Ibidem, s. 7). Rekomendują też innym organizacjom pomocowym, by „odmawiać przyjmowania finansowania od donatorów, jeśli warunkiem uzyskania wsparcia jest współpraca z wojskiem lub dostarczanie mu informacji, lub też wymaga się od nich dystrybuowania pomocy i przydzielania środków w zależności od współpracy politycznej lub wojskowej ze strony beneficjentów pomocy" (Ibidem, s. 7).

UE przez wiele lat nie angażowała się w rozwiązywanie konfliktów poprzez operacje wojskowe. Pierwszą decyzję o wysłaniu wojsk poza Europe podjęła dopiero

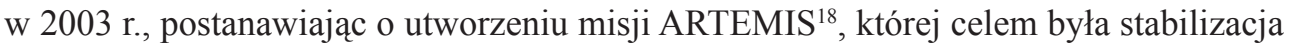
prowincji Ituri (DRC). UE stosukowo rzadko angażuje się w klasyczne misje wojskowe. Było ich tylko kilka i zawsze wiązały się z mandatem ONZ-tu: EUFOR DR Kongo (2006), EUFOR Czad/RCA (2007-2009), EUNAVFOR Atalanta (2008-), EUFOR RCA (2014-2015). Misje te zrealizowały wyznaczone im cele, ale były względnie małe pod względem liczby uczestników, długości trwania (z wyjątkiem Atalanty) i zakresu udzielonego mandatu. Wynika to z braku instrumentów niezbędnych do rozwiązywania kryzysów oraz „tradycyjnego podejścia państw członkowskich do rozwiązywania konfliktów w byłych państwach kolonialnych - gdy mają one miejsce w byłych koloniach, metropolie czują się zobowiązane do rozwiązywania konfliktów wcześniej, niż podjęta zostanie decyzja na poziomie UE. Często zatem misja unijna jest de facto zalegalizowaniem działań państwa członkowskiego, mającego tradycyjne interesy w regionie konfliktu” (Frankowski, Słomczyńska, 2011, s. 165).

Misji UE o charakterze cywilnym, policyjnym lub szkoleniowym, związanych z bezpieczeństwem i pokojem, było znacznie więcej niż misji wojskowych. Wielość misji nie jest jednak dowodem na to, że Afryka jest priorytetem UE w zakresie bezpieczeństwa. UE nigdy nie była i nadal nie jest gotowa do interweniowania w Afryce na dużą skalę. Postawa Unii wobec interwencji wojskowych w Afryce jest, w gruncie rzeczy, paradoksalna. Najczęściej postawa ta opisywana jest tak: „nie należy oczekiwać, że państwa UE zdecydują się wysłać swoich żołnierzy w obszar konfliktu bez gwarancji bezpieczeństwa dla nich" (Ibidem, s. 199). Kto miałby to bezpieczeństwo

${ }_{18}$ Council Joint Action 2003/423/CFSP of 5 June 2003 on the European Union military operation in the Democratic Republic of Congo, OJ L 147, 14.06.2003. 
gwarantować? Gdyby jednak znalazł się ktoś kto na danym terenie ma takie możliwości, to raczej nie potrzebowałby tam europejskich żołnierzy. Koncept, że warunkiem wysłania żołnierzy w rejon konfliktu jest zagwarantowanie im bezpieczeństwa silnie ogranicza potencjalne działania wojskowe UE. Drugim poważnym ograniczeniem są wysokie koszty takich misji.

\section{Instrumenty współpracy UE na rzecz pokoju i bezpieczeństwa}

UE chętnie wspierała liczne misje wojskowe innych podmiotów, a w szczególności ONZ i Unii Afrykańskiej (AU). Aby ułatwić to wsparcie, podjęto konkretne działania, których celem było utworzenie mechanizmów wspieranie pokoju i bezpieczeństwa w Afryce. Nie mogły one być częścią budżetu UE, gdyż traktaty UE nie pozwalają Wspólnocie na finansowanie operacji wojskowych. W 2003 r. decyzją Rady Ministrów AKP-UE ustanowiono Instrument na rzecz Pokoju w Afryce (APF) ${ }^{19}$. Jego zadaniem jest finansowanie misji pokojowych w Afryce. O ustanowienie takiego instrumentu wnioskowała $\mathrm{AU}^{20}$, która chciała by fundusze na wsparcie pokoju i bezpieczeństwa w Afryce były bardziej przewidywalne (Sustaining EU, 2011, s. [2]). Podstawą prawną powołania APF była Umowa z Kotonu, w której stwierdza się: „W sytuacjach gwałtownych konfliktów Strony podejmą wszelkie działania właściwe w zakresie zapobiegania nasilaniu się przemocy, ograniczenia zasięgu terytorialnego oraz ułatwienia pokojowego rozstrzygnięcia zaistniałych sporów" (art. 11, ust. 4). Pierwotnie instrument wyposażono w kwotę 250 mln euro (art. 2), pochodzących z 9-ego EDF. W 2006 i 2007 r. fundusze AFP powiększono o $189 \mathrm{mln}$ euro. W 2006 r. przedłużono jego działanie na lata 2008-2010, a rok później zasilono kwotą $300 \mathrm{mln}$ euro, pochodzących z 10-ego EDF (2008-2013). Po kolejnych zwiększeniach z roku 2011 i 2012 - łącznie na lata 2009-2012 - APF został wyposażony w kwotę 700,6 mln euro. Program Działania APF na lat 2014-2016 obejmuje kwotę $750 \mathrm{mln}$ euro.

Fundusze te były, przede wszystkim, przeznaczane dla państw afrykańskich, które w ramach misji pokojowych wysyłają swych żołnierzy do innych państw afrykańskich. Robią to w ramach operacji wsparcia pokoju. Jednak w związku ze źródłem finansowania (EDF) w ramach APF można finansować tylko takie wydatki, które są kwalifikowane jako pomoc rozwojowa. Zalicza się do nich koszt utrzymania żołnierzy (w tym diety), koszty łączności i transportu, opiekę zdrowotną i amortyzację urządzeń cywilnych. Nie można natomiast finansować żołdu, zakupu broni i sprzętu wojskowego, amunicji czy kosztów szkolenia wojskowego. W ramach instrumentu finansowano m.in. misje wojskowe UA i afrykańskich organizacji regionalnych: AMIS w Sudanie (2004-2007), AMISOM w Somalii (2007-), AMISEC - misja zabezpieczająca wybory na Komorach (2006-2008), MICOPAX (pierwotnie FOMUC) w RCA (2004-2013), a także mediacje na Madagaskarze, w Nigrze, Gwinei i Somalii. Instrument, w ramach budowania możliwości instytucjonalnych, finansuje również regionalne organizacje afrykańskie (EPLO,

${ }^{19}$ Decision No 3/2003 of the ACP-EC Council of Ministers of 11 December 2003 on the use of resources from the long-term development envelope of the ninth EDF for the creation of a Peace Facility for Africa, OJ L 345/2003, 31.12.2003.

${ }_{20}$ African Union Maputo Summit Declaration. 
2012, s. 4) oraz instytucje i mechanizmy, które w ramach struktury APSA, mają ułatwić zapewnienie pokoju w poszczególnych regionach Afryki.

Drugim instrumentem finansowym UE bezpośrednio związanym $\mathrm{z}$ bezpieczeństwem, a w tym bezpieczeństwem m.in. w Afryce jest Instrument na rzecz Stabilizacji i Pokoju (IcSP) ${ }^{21}$. Jego poprzednikiem był, ustanowiony w 2006 r., Instrument na rzecz Stabilności (IfS) ${ }^{22}$, który zastapił z kolei wcześniejszy Mechanizm Szybkiego Reagowania $(\mathrm{RRM})^{23}$. Ogólnym celem Instrumentu jest wspieranie cywilnych działań prewencyjnych, które mogą zneutralizować zagrożenia dla bezpieczeństwa. Najnowsza wersja instrumentu, zgodnie z wolą państw członkowskich UE: „zapewnia na lata od 2014 do 2020 bezpośrednie wsparcie polityk zewnętrznych UE przez usprawnienie i zwiększenie spójności działań Unii w dziedzinach reagowania kryzysowego, zapobiegania konfliktom, budowania pokoju oraz gotowości na sytuacje kryzysowe, a także przeciwdziałania zagrożeniom o charakterze globalnym i ponadregionalnym" (art. 1, ust. 1).

W latach 2007-2013 planowano w ramach IfS wydać 2,062 mld euro. W kolejnej perspektywie finansowej - na lata 2014-2020 na IcSP zarezerwowano 2,338 mld euro (art. 13). Instrumenty wspierające stabilność nie mają ograniczeń geograficznych, a SSA jest jednym z kluczowych beneficjentów. W latach 2007-2013 w ramach IfS w Afryce wydano ponad 316 milionów euro. Większość funduszy Instrumentu jest wydawane na krótkoterminowe projekty, które nie podlegają wcześniejszemu programowaniu. Wynika $\mathrm{z}$ to prewencyjnego charakteru działań finansowanych $\mathrm{w}$ ramach tego mechanizmu. IfS, zarządzany przez FPI, jest szybszy niż inne instrumenty UE. Jednak szybkość uruchomienia funduszy jest oceniana jako niewystarczająca dla instrumentu, mającego stabilizować sytuacje konfliktowe (EU Development, 2013, s. 21). Z analiz wynika, że minimalny okres między zidentyfikowaniem potrzeby a rozpoczęciem interwencji w ramach IfS wynosi dwa miesiące (Ibidem, s. 21). Maksymalny okres finansowania $z$ IfS wynosi 24 miesiące. Dłuższe interwencje teoretycznie powinny być finansowane $\mathrm{z}$ DCI. W praktyce jest $\mathrm{z}$ tym problem. Jest to związane $\mathrm{z}$ faktem, że problematyka zapobiegania konfliktom jest często pomijana w dokumentach programujących DCI - Country Strategy Papers i Regional Strategy Papers (Ibidem, s. 40). Najwięcej funduszy IfS wykorzystano w DRC, RCA, Czadzie i Somalii. Pozostali beneficjenci w Afryce to: Uganda, Gwinea-Bissau, Sudan, Zimbabwe, Sierra Leone, Senegal, Zambia, Komory, Seszele, Madagaskar, Kenia i Burundi. W ramach IcSP nie finansuje się wyłącznie klasycznych misji cywilnych. Na przykład w roku 2014 wspierano budowanie państwowości w państwach, dotkniętych epidemią wirusa ebola - w Gwinei, Sierra Leone i Liberiii ${ }^{24}$.

Kolejnymi instrumentami UE służącymi do finansowania działań związanych z redukowaniem niestabilności są: budżet Wspólnej Polityki Zagranicznej i Bezpieczeństwa

${ }^{21}$ Rozporządzenie Parlamentu Europejskiego i Rady (UE) nr 230/2014 z dnia 11 marca 2014 r. ustanawiajace Instrument na rzecz przyczyniania się do Stabilności i Pokoju, Dz. U. L 77/2014, 15.03.2014.

${ }^{22}$ Rozporządzenie (WE) Parlamentu Europejskiego i Rady nr 1717/2006 z dnia 15 listopada 2006 r. ustanawiajace Instrument na rzecz Stabilności, Dz. U. L 327, 15.11.2006.

${ }^{23}$ Rozporządzenie Rady (WE) nr 381/2001 z dnia 26 lutego 2001 r. tworzqce mechanizm szybkiego reagowania, OJ L 057/2001, 27.02.2001.

${ }^{24}$ Sprawozdanie roczne z 2015 r. na temat polityki rozwoju i pomocy zewnętrznej Unii Europejskiej oraz wdrażania tych polityk w 2014 r., COM (2015) 578. 
(w latach 2007-2013 była to łączna kwota 1980 mln euro) oraz mechanizm ATHENA ${ }^{25}$ (ok. 520 mln euro w latach 2004-2010). ATHENA jest mechanizm ,zarządzania finansowaniem wspólnych kosztów operacji Unii Europejskiej mających wpływ na kwestie wojskowe i obronne" (art. 2). Wydatki operacyjne WPZiB, będące częścią budżetu UE, są przeznaczane na działania cywilne, realizowane przez podmioty cywilne. Środki te są zapisane w specjalnej podsekcji (rozdział 19 03), która stanowi część tytułu 19 (stosunki zewnętrzne). Z budżetu WPZiB finansowano m.in. misje EUSEC DR Kongo, EUPOL DR Kongo, EU RSB Gwinea-Bissau.

\section{Wnioski}

Samo rozwiązanie konfliktu, polegające na doprowadzeniu do zaprzestania walk i przywrócenia pokoju, nie likwiduje automatycznie przyczyn konfliktów. J. K. Stearns pisał: „Łatwiej jest naprawiać drogi czy szkolić policję niż zmienić głęboko zakorzenione obyczaje osób będących w tym regionie u władzy. Darczyńcy «przerabiali» tę lekcję w Afganistanie. W miejscu, gdzie toksyczna polityka protekcjonizmu, transgranicznych interwencji i rozdrobnienie sceny politycznej utrwalają przemoc" (Stearns, 2013, s. 112). Kluczowi donatorzy, jak UE, mają poważne trudności zarówno z wolą zaangażowania w misje pokojowe, jak i ulepszeniem koordynacji czy przekonaniem afrykańskich partnerów do rzeczywistego uznania uniwersalności praw człowieka w ich euroatlantyckiej interpretacji. Dodatkowo, Unia inaczej - niż większość państw afrykańskich - postrzega podmiot bezpieczeństwa. „Stosując podejście zachodniocentryczne, zgodne ze współczesnym dyskursem o bezpieczeństwie, można stwierdzić, że bezpieczeństwo jednostki stoi na równi z bezpieczeństwem państwa" (Frankowski, Słomczyńska, 2011, s. 163). Tymczasem w wielu państwach SSA za uzupełniający podmiot bezpieczeństwa nie uchodzi cała ludność tylko aktualnie rządzący. Rządzący w takich państwach bronią państwa, gdyż często wykorzystują państwo dla własnych partykularnych interesów. Losem ludności, jej bezpieczeństwem i rozwojem, rządzący wielu państw afrykańskich nie interesują się.

UE ma również problem wynikający z tego, że struktura instytucjonalna UE w sprawach polityki zagranicznej często uniemożliwia podejmowanie szybkich decyzji. $Z$ drugiej strony od szybkości podejmowania decyzji często zależy skuteczność działań zmierzających do zapobieżenia konfliktom czy ich rozwiązywania. Komisja Europejska, zarządzająca IcSP i AFP, wkracza w obszar polityki zagranicznej, która traktatowo pozostaje kompetencją państw członkowskich i Rady.

Z analizy sytuacji państw SSA wynika, że trwały, zrównoważony rozwój w warunkach wojny czy innych konfliktów zbrojnych nie jest możliwy. Budowanie trwałego rozwoju musi być poprzedzone skutecznym zakończeniem konfliktów oraz wyeliminowaniem lub radykalnym ograniczeniem ich przyczyn. Pomoc z zewnątrz, w tym pomoc UE, ma w tych krajach - przede wszystkim - charakter pomocy humanitarnej. Jest ona potrzebna i ratuje ludzkie życie. Sama w sobie nie likwiduje jednak przyczyn konfliktów, ani nie jest w stanie zapewnić trwałego rozwoju. W przypadku państw o najgorszej

${ }^{25}$ Decyzja Rady 2004/197/WPZiB z dnia 23 lutego 2004 r. ustanawiajaca mechanizm zarzadzania finansowaniem wspólnych kosztów operacji Unii Europejskiej majacych wplyw na kwestie wojskowe i obronne, Dz. U. L 63/68, 28.02.2004. 
sytuacji, pomoc humanitarna nie wpływa też w istotny sposób na zmniejszenie tendencji migracyjnych. Rozwój społeczny i gospodarczy państw SSA, doświadczających powtarzających się konfliktów zbrojnych i niestabilności jest zatem uzależniony w pierwszej kolejności od rozwiązań politycznych, a nie ekonomicznych.

\section{Bibliografia}

$11^{\text {th }}$ EADI General Conference. Insecurity and Development. Regional issues and policies for an interdependent world (2006), European Association of Development Research and Training Institutes, Bonn.

African Economic Outlook 2015, www.africaneconomicoutlook.org.

Africa's Turn. A Conversation With Macky Sall (2013), "Foreign Affairs", vol. 92, no. 5 September/ October 2013, New York.

Debiel T., Werthes S. (2006), Fragile States and Peace-buliding, w: Global Trends 2007. Vunerability and Human Security in the $21^{\text {st }}$ Century, red. T. Debiel, D. Messner, F. Nuscheler, Development and Peace Foundation, Bonn.

Development and Security: Two sides of the same coin. Report of the seventh Development Policy Forum (DPF) roundtable (2009), Friends of Europe, Brussels.

EPLO Briefing Paper 3/2012 The African Peace Facility (2012), Brusseles.

EPP-ED Development Charter. 100 points for a better world (2008), EPP-ED Group in the European Parliament, Brussels.

EU Development Cooperation in Fragile States: Challenges and Opportunities. Study (2013), European Parliament, Brussels.

Fragile States Index 2015 (2015), The Fund for Peace, Washington.

Frankowski P., Słomczyńska I. (2011), Unia Europejska - Afryka Subsaharyjska. Uwarunkowania. Mechanizmy. Efektywność wspólpracy, Wydawnictwo Uniwersytetu Marii Curie-Skłodowskiej, Lublin.

Huliaras A. (2009), EU-Africa Relations: Dealing with the Challenges of the Future, Centre for European Studies, Brussels.

Kibreab G., National service in Eritrea. Miserable and useless, „The Economist”, 10.03.2014.

Kto niesie pomoc? Upolitycznienie pomocy w konfliktach i kryzysach (2011), Oxfam International, Oxford.

Meredith M. (2011), Historia wspótczesnej Afryki. Pół wieku niepodległości, Wydawnictwo Akademickie DIALOG, Warszawa.

Promoting Democracy. Creating Peace. Shaping Globalisation (2005), The Friedrich-Ebert-Stiftung, Bonn.

Raport Europejski o Wspótpracy 2009, Przezwyciężanie niestabilności w Afryce (2009), Ośrodek Studiów Wyższych Roberta Schumana przy Europejskim Instytucie Uniwersyteckim, San Domenico di Fiesole.

Report on the Fact-find Mission to the Horn of Africa (Eritrea, Djibouti, Ethiopia) (2008), Committee on Development, European Parliament.

Sen A. (2000), Development as Freedom, Anchor Books, New York.

Solorz M. W. (2004), Francja wobec Afryki subsaharyjskiej, Oficyna Wydawnicza ASPRA-JR, Warszawa.

Stearns J. K. (2013) Helping Congo Help Itself. What It Will Take to end Africa's Worst War, "Foreign Affairs", vol. 92, no. 5 September/October 2013, New York. 
Sustaining EU Financing for Security and Development: The Difficult case of the African Peace Facility. Briefing Paper 7/2011 (2011), German Development Institute, Bonn.

The Africa-European Union Strategic Partnership (2008), Council of the European Union, Brussels.

The Least Developed Countries Report 2014 (2014), United Nations, New York.

Transforming our world: the 2030 Agenda for Sustainable Development. Resolution adopted by the General Assembly on 25 September 2015. A/RES/70/1, United Nations.

Wulf H. (2010), Military Security between Rearmament, Democratisation and Privatisation, w: Global Trends 2010. Peace-Development-Environment, red.) T. Debiel, D. Messner, F. Nuscheler, M. Roth, C. Ulbert, Development and Peace Foundation, Bonn.

\section{The Importance of Peace and Stability for European Development Policy Towards Sub-Saharan Africa}

\section{Summary}

The aim of the global development policy is to eradicate poverty. Scholars are in no doubt that wars and armed conflicts are among the key obstacles to the effective struggle against poverty. Peace and security are as important for developing countries as for those that offer development aid. The EU and its member states are the greatest global providers of aid and Sub-Saharan Africa (SSA) is the region with the highest demand for developmental aid. This article analyzes the position of peace and stability in European development policy towards Africa. Another issue is the attempt to answer the question of the influence peace and stability, or their lack, have on the development of SSA. The analysis of the situation in SSA states demonstrates that consistent and sustainable development is not feasible during warfare and other armed conflicts. Ensuring permanent development has to be preceded by an effective conclusion of conflicts and the eradication or dramatic suppression of the causes of such conflicts. The aid from outside, including that provided by the EU, is first and foremost humanitarian. While such aid is necessary and helps save human lives, it neither eliminates the reasons for conflicts, nor is it able to ensure permanent development.

Key words: Africa, development, security, European Union, instability 